\title{
REVIEW \\ Village Leaders and Rural Development in Bangladesh
}

\author{
Kazuo ANDO ${ }^{1}$, Haruo UCHIDA ${ }^{2,5 *}$, Habibur RAHMAN ${ }^{3}$ and \\ S.M.Altaf HOSSAIN ${ }^{4}$ \\ ${ }^{1}$ Center for Southeast Asian Studies, Kyoto University (Kyoto, Kyoto 606-8501, Japan) \\ ${ }^{2}$ Department of Hilly Land Agriculture, Shikoku National Agricultural Experiment Station \\ (Zentsuji, Kagawa 765-0053, Japan) \\ ${ }^{3}$ Department of Agricultural Economics, Bangladesh Agricultural University \\ (Mymenshingh 2002, Bangladesh) \\ ${ }^{4}$ Department of Agronomy, Bangladesh Agricultural University (Mymenshingh 2002, Bangladesh)
}

\begin{abstract}
A village committee was established to look after rural development activities that were initiated by joint efforts of villagers and staff members of the Joint Study on Rural Development Experiment (JSRDE) project team sponsored by JICA in Bangladesh. The committee was formed of the so-called traditional village leaders, or matabbors, some of whom proved to be active in enhancing villagers' unity and devotion to village public affairs. At the same time, a village coordination meeting of local government officers was formed to coordinate the activities of the government concerning rural development. The Thana (local administrative office) officer played pivotal roles in organizing the meeting. An effort was made to "link" the organizations of local governments and the village committee, so that the governments' rural development services were channeled into the village through a public, formal "door" of the village. Various trials implemented in the village indicated that successful linkage hinges upon the single facet of "openness" or "transparency" in information dissemination, which had been rather lacking in rural Bangladesh. The important processes of formulating the village committee and the village coordination meeting of local governments and clues for successful communication and dissemination of related information are documented in this paper. Moreover, analysis of an economic aspect of rural infrastructure reveals that bridge construction in the village was efficient in generating income for the poor.
\end{abstract}

Discipline: Agricultural economics

Additional key words: administrative service delivery, information transparency, people's participation, rural infrastructure, village committee

\section{Introduction}

Existence of local leaders, or matabbors, has been negatively evaluated in the field of rural development in Bangladesh. Since poverty alleviation is the first priority of rural development programs ${ }^{6}$, program implementers believe that local leaders, most of them belonging to a well-off group in the village, should be kept outside of the target population.

A characteristic of rural development programs aiming at people's participation implemented so far, is that most of their activities put stress on training, savings and credit, etc., which approach local people individually, and as a result programs requiring communal participation, such as construction of rural infrastructure, are rarely

This paper reports the results obtained in the joint project with the Government of Bangladesh on "Joint Study on Rural Development Experiment (JSRDE)" during 1992 to 1995 sponsored by the Japan International Cooperation Agency. The paper is based primarily on our previous study entitled "Matabbors and Village Development: An Account of Action Research in Dakshin Chamuria Village, Bangladesh" (in Japanese) submitted to Tonan Ajia Kenkyu' and others ${ }^{2,3,4}$. However, large parts of the papers have been revised.

Present address:

${ }^{5}$ Greenhouse Research Team for Hilly and Mountainous Areas, WeNARC, NARO (Zentsuji, Kagawa 765-0053, Japan)

*Corresponding author: e-mail uchidah@affrc.go.jp

Received 13 July 2007; accepted 27 November 2007. 
included in their activities. It can be said that such programs require both the community consciousness of villagers and leadership for coordinating among villagers and across villages, yet such programs used to exclude the local leadership.

On the contrary, the basic approach of our trial, under the Joint Study on Rural Development Experiment (JSRDE) project funded by JICA from 1992 to 1995, in the village of Dakshin Chamuria (D village hereinafter), is to encourage local people's participation through positively adapting the rural society (Fig. 1). This is to say, to draw on the community consciousness of local people, by encouraging the function of local leaders as the motivators of local society. The concept of this approach has been developed through observations of various occurrences, in which matabbors played various roles, such as when villagers endeavor to protect their village from floods under their leadership, and their involvement in uniting villagers' actions for constructing village schools and bazaars, processing and distributing relief goods from government, etc.

Several activities have been tried in D village. A village committee was organized covering the whole village, and led by it, programs such as improvement of rural infrastructure have been planned and implemented. A village coordination meeting was organized, in which strengthening the linkage between government and villagers through services has been tried. This paper aims at examining the possibility of an alternative approach to

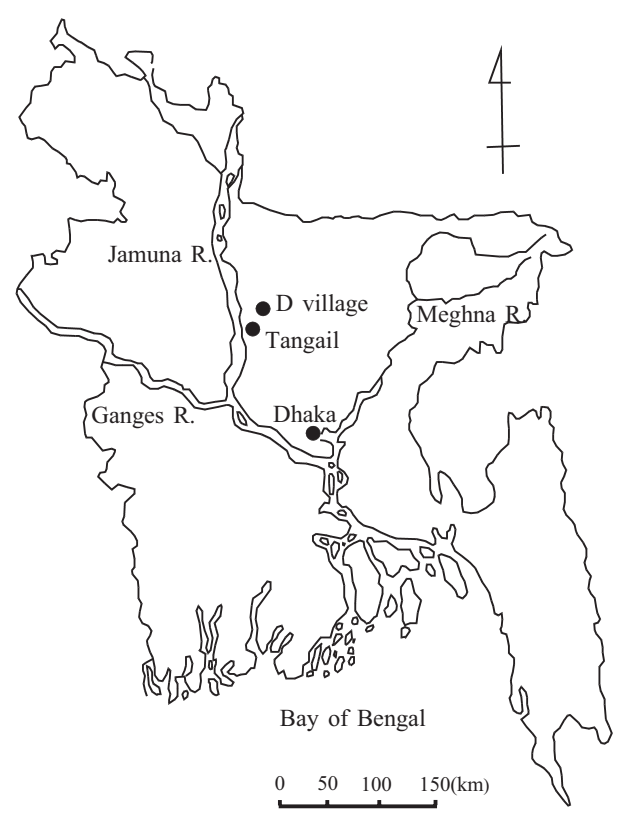

Fig. 1. Location of Dakhshin Chamuria (D) village rural development, not putting emphasis on the economic improvement of individuals, which used to be the mainstream of rural development in Bangladesh, but emphasizing and encouraging communal unity of the villagers by the leadership of matabbors. In this paper, our trials for an alternative approach to rural development are introduced. At the same time, the paper analyzes an economic aspect of the rural infrastructure for transportation, namely a bridge, which was long-sought after by the villagers and built in the village.

\section{Matabbor and "public" in D village}

Although we tend to imagine that local leaders must be elites endowed both with a superior economical condition and academic career, actually such conditions are not necessarily the prerequisites for being a matabbor. Among matabbors, there are those who have no more than 1 acre, or 0.4 ha, of land, and furthermore some of them are illiterate. Most of the matabbors are in their forties or above ${ }^{5}$.

Matabbors have never been elected in a village gathering or through a legal procedure, they are spontaneously acknowledged as matabbors by the villagers. Villagers explain that they acknowledge them as matabbors because "they belong to the well-off class in the village" or "they have been trained to be matabbors by their fathers who also used to be matabbors", which does not, however, necessarily mean a matabbor position is regarded as hereditary. Becoming a matabbor is a question of knowing a wide range of information and being a good mediator with conversational skills. Among such qualities, eloquence is a prerequisite to be an influential matabbor.

Matabbors know much about the personal affairs of villagers, but they pay more attention to the public matters in the village. When they try to persuade villagers, they would often use phrases such as "society of the village" and "not for oneself, but for all villagers". In this way, matabbors settle quarrels among villagers, or organize villagers for rural development work, trying to remind villagers of the community consciousness.

A good and important example of matabbors working for the sake of the public can be well observed in the village courts. The court at the village level is held several times in a year. There were 13 matabbors who participated in settling inter-village matters at the village court. Matabbors are entitled to serve as court mediators or judges by villagers. The principle that they should abide by the decision of the matabbors acknowledging they are made without selfish motives, has been cherished in the mind of villagers for generations. Generally, a court can be held several times in the case a quarrel can not be 
settled in one court. When it is complicated, matabbors from nearby villages are also invited as mediators, and if the village court becomes dead-locked, an odd number of matabbors are gathered for making a special discussion by majority. Court decisions are made by the mutual consent of all parties, and with the approval and public consent of the villagers even though legally they are not legitimately settled.

Besides functioning as mediators in village courts, matabbors function in contacting organizations outside the village such as government agencies, or NGOs who are implementing rural development programs. More than $70 \%$ of matabbors go to the local administrative office more than once a month. Matabbors actively gather useful information keeping in mind current trends in government, NGOs, and so forth. On the other hand, when outside organizations attempt to start some program in the village, they usually approach the matabbors for collecting useful information on the village. So matabbors can get various information earlier than other villagers and they can monopolize profitable information. It is often observed in the village that tricky matabbors act selfishly and monopolize profitable information, and such matabbors have been criticized as "touts" by those who are concerned with rural development programs.

When the abuse of matabbors privileges, such as monopolizing profitable information, becomes too unforgivable, villagers strongly protest against them. Some cases in the past indicated the importance of the penetration of information among villagers for checking the abuse of privilege by matabbors.

\section{Action programs in D village}

\section{Establishment of the village committee}

Matabbors demonstrate their leadership when villagers face problems which require unity of the villagers for solution. On such occasions, matabbors act as the authority of the village appealing to the community interest of the villagers. When matabbors act only for their own interest, they have the tendency to become touts, and we know that it is a simple but very effective way to prevent such a liability by making everybody aware of useful information that tends to be monopolized by matabbors. Thus, the village committee was established in D village to make matabbors reveal information and discuss their opinions in person in front of the villagers.

A village in Bangladesh usually consists of several small communities called 'para'. D village has 4 communities and each of these has several matabbors. To set up a village committee, a general meeting was held in the classroom of the primary school in the village on January

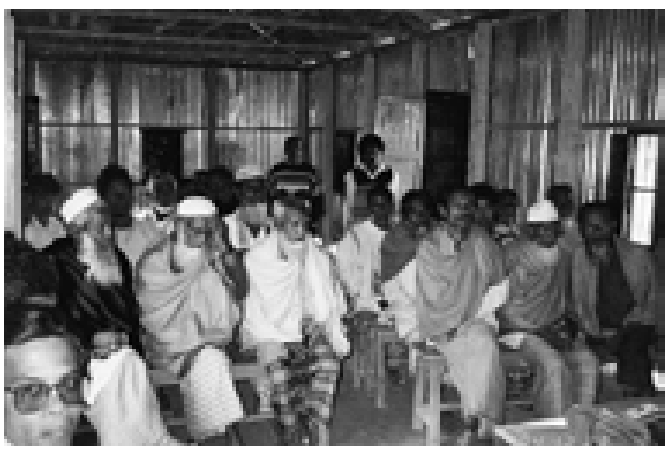

Photo 1. Village committee meeting

2, 1993. The selection of the matabbors as committee members was carried out during this meeting by about 200 people from all communities. Matabbors from each community were selected according to the number of households in each community. The committee had 18 members including 4 females, 1 from each community. Other procedures included the selection of the executing body, a chairman and secretaries on the basis of the villagers' recommendation (Photo 1).

The village committee is assumed to fulfill the following 3 main functions: (1) to hold a monthly meeting for discussing the common problems, (2) to prepare programs for possible solutions, (3) to hold a coordination meeting (see next section) with the field assistants of the rural development agencies, the government and NGOs.

The village committee works as the contact point for the reception and negotiation with organizations outside the village, which used to be handled personally by matabbors, in addition to functions such as identification and guidance of development activities in the village, coordination of villagers' problem, and so forth. The village committee is the representative and the authority of the village, and all programs would be implemented through the approval of the committee.

\section{Village coordination meeting for government service delivery}

Various administrative services in the fields of agricultural extension, public health, fishery, livestock, etc., are supplied in the villages of Bangladesh. Those who are in charge of delivering the services to the villagers are field assistants who go around villages and local administrative officers who are in charge of supervision of the field assistants. Their work starts by contacting the matabbors who function as their guides in the villages, and continues as a personal relationship. Transfer of the services to the villagers through matabbors can be observed in the process of selecting contact farmers for agricultural exten- 
sion service programs, establishment of governmental cooperatives, receiving subsidies from government, receiving relief goods, etc. In the process, matabbors select themselves or those who are personally intimate as the beneficiaries of the services, and others in the general population of the village would not be informed of the existence of such services until they see someone selected who is receiving the services and they often even do not know that services have been delivered.

When thinking of the linkage between government service and villagers, it is important not only to give anyone an equal chance to access the services who wants them but also to have a counter system for conveying villagers' needs to the officers. In addition, the system should be the one that fosters the community consciousness of the villagers, since our approach of rural development is based on it. Hence, the village coordination meeting was also established so that the villagers can get the information of service delivery directly from the field assistants and so that the villagers can indicate their needs.

The meeting is managed by the secretariat of village committee chaired by local administrative officer. All members of the village committee and the representatives from the unit of homestead out of two to four huts, are invited. Seven field assistants from each service section, a field worker from NGO, a secretary, and a member of the union council attend the meeting. The meeting is held every first Thursday, each field assistant and worker reports what he/she did last month, and informs the village of the schedule and content of services that will be delivered in coming month along with other important topics.

Information addressed in the meeting is printed in a paper, and distributed to the villagers. It is a simple information paper with only one or two pages edited in the project office. They are put on the notice boards installed in each community, school yard and bazaar, as well as delivered to the villagers by circular notice.

Visits of field assistants and workers had not been well known to the villagers before the program started, but with the facilitation of service delivery system by the meeting, circular notice, and notice boards, the villagers developed the ability to approach the field assistants more easily. For example, a livestock assistant gave the vaccination to cattle amounting to 100 on September 1993, whose activity used to be seldom known to the villagers before. Governmental services have come to be visible to the villagers.

\section{Economics of infrastructure building}

\section{Matabbors working for hat establishment and bridge construction}

Villagers who had to go off shopping far out of D village had wanted to establish a hat, or weekly market, in their own village for a very long time. Establishment of a hat was first proposed by one of the influential matabbors of the village in 1986. He called on seven nearby villages' matabbors and proposed to them to hold a hat in the prayer yard on the western border of D village. Matabbors of each village returned to their village, and discussed about it and they gathered again. On the next meeting, establishment of a hat was decided and a committee for discussing necessary issues was organized. In this way, the hat started in D village under the leadership of plural villages' matabbors, and it is held in the afternoon every Saturday. The hat has been developed gradually, and stalls of groceries, a dispensary, and a barber are standing at present and many people gather from neighboring villages. Foresight and insight of matabbors for the impact of the hat on the rural economy seemed to be proved.

There were broken-down sections on the road which interrupted the traffic from the highway to D village in the rainy season. As the hat opened and the marketplace of D village was a breath of life to the villagers, the village committee, namely matabbors, decided to request that the government construct a bridge on the longest brokendown section to allow van-rickshaws carrying burdens and people to the hat to come and go freely even in the rainy season. It was requested that vehicles could come at the bridge smoothly from the highway along the road for a bridge construction by the government. It was necessary to level the road and set culverts on two broken-down sections, one was in the neighboring village, by the villagers themselves. Accordingly, matabbors of D village were busily engaged to collect contributions and pro bono work for land elevation showing their own volunteer works, and persuaded the owners to provide their land in order to set culverts. Moreover, they negotiated with the matabbors of the neighboring village to repair the road in their village. As the result of their enormous efforts, finally, the $15 \mathrm{~m}$ concrete bridge was constructed during the JSRDE period.

\section{Economical assessment of the hat and bridge}

The authors estimated the economic impact of the infrastructure by a hat survey and the number of van-rickshaws before bridge construction. The neighboring village, which is accessible to the highway directly, had 18 van-rickshaws used for transporting commercial goods to the hat and D village only 7 . Therefore, the new infra- 
Table 1. Cost and benefit of estimated impact of the bridge

\begin{tabular}{cccc}
\hline \hline $\begin{array}{l}\text { Earning by a van-rickshaw } \\
\text { per month (Tk.) }\end{array}$ & $\begin{array}{l}\text { Total earning in a year by } \\
\text { 11 van-rickshaws (Tk.) }\end{array}$ & $\begin{array}{l}\text { Total cost of the } \\
\text { bridge (Tk.) }\end{array}$ & $\begin{array}{l}\text { Annual cost of the bridge } \\
\text { (average of 30 years) (Tk.) }\end{array}$ \\
\hline 1,000 & 132,000 & 750,000 & 25,000 \\
1,200 & 158,400 & & \\
\hline
\end{tabular}

1 dollar $=65 \mathrm{Tk}$

Table 2. The estimated impact of the weekly hat by numbers of total participants including small merchants surveyed on three occasions

\begin{tabular}{|c|c|c|c|}
\hline Condition & $\begin{array}{l}\text { Bad communication } \\
\text { Rainy season } \\
\text { Aug. } 17,1994\end{array}$ & $\begin{array}{l}\text { Good communication } \\
\text { Dry season } \\
\text { Jan. } 7,1995\end{array}$ & $\begin{array}{l}\text { Highest potential } \\
\text { Just before Eid festival } \\
\text { Feb. } 26,1995\end{array}$ \\
\hline Person (No.) & 1,946 & 2,941 & 4,198 \\
\hline Villages (No.) & 32 & 34 & 43 \\
\hline \multirow[t]{4}{*}{ Buying capacity } & 2,000 person & 3,000 person & 4,000 person \\
\hline & $10 \mathrm{Tk} . /$ person & 10 Tk./person & $10 \mathrm{Tk} . /$ person \\
\hline & 4 hat/month & 4 hat/month & 4 hat/month \\
\hline & $80,000 \mathrm{Tk} . / \mathrm{month}$ & $120,000 \mathrm{Tk} . / \mathrm{month}$ & $160,000 \mathrm{Tk} . / \mathrm{month}$ \\
\hline (Per season) & 480,000 Tk./6 months & $720,000 \mathrm{Tk} . / 6$ months & $960,000 \mathrm{Tk} . / 6$ months \\
\hline
\end{tabular}

structure has the potentiality in increasing the number of van-rickshaws by 11. The estimated impact of the bridge is shown in Table 1. The table explains the good prospect of investment for infrastructure development in D village. As total cost of the bridge was 750,000 Tk., 1 dollar equals $65 \mathrm{Tk}$., the annual cost is simply calculated to be 25,000 $\mathrm{Tk}$. if the life of the bridge is 30 years. This cost is seemingly somewhat big. However, the increased 11 van-rickshaw pullers can earn $132,000 \mathrm{Tk}$. to $158,400 \mathrm{Tk}$. annually. They are a low-income group but they are considered to be small entrepreneures. This indicates that the development of infrastructure with a long term perspective has a good prospect for the development of small entrepreneurship among the poor. So the credit loan programs to the poor should be implemented in accordance with the infrastructure programs.

The annual cost of 25,000 Tk. should be collected from the direct beneficiaries and a subsidy of the central government fund. At the weekly hat about 200 small merchants gather to sell their goods and so the 218 persons (18 van-rickshaw pullers and 200 small merchants) will use the bridge directly. If they would pay subscription of only $2 \mathrm{Tk}$. for bridge per week, the total subscription per year amounts to 22,672 Tk. Only the remaining 2,328 Tk. is to be supported by a subsidy of the central government.

The direct impact of infrastructure of the bridge can be estimated in terms of the number of participants to the weekly hat as shown in Table 2. The table indicates that the income in the rainy season from the hat would increase 240,000 Tk., balance of two seasons, due to good road communication. The maximum potential of the hat is considered on participants of the hat just before Eid festival. If we develop the hat to the maximum potential, volume of trade transacted can amount to be double of the rainy season. During the rainy season, work in the village, namely making local cigarettes, handloom and agricultural labor decrease due to the weather condition. Therefore, the hat is the only facility to the poor which offers opportunity of income generation by selling something or transporting goods. The hat development program must be given top priority for poverty alleviation in rural Bangladesh.

\section{Conclusion}

The characteristics of our approach tried in D village is that we placed existing rural society as the supporter of the rural development, not thinking of introducing new organization such as cooperatives or target groups. Experiences of rural development in the village taught us that it is local leaders, namely matabbors, who can draw full participation by villagers for rural development program.

The hat establishment and bridge construction program revealed the additional importance of matabbors as 
coordinators externally. As the impact of infrastructure building spreads over several villages, the importance of discussion among matabbors in the area could increase rather than decrease. Here, we feel the needs for recognizing the function of matabbors to communicate with each other among the villages. Consequently, it is our alternative method for rural development to recognize the authority of matabbors, which has been denied in the field of rural development in Bangladesh, and bring out their abilities in the village and functions as coordinators in the locality. Establishment of the village committee aims at the systematic approach considering such a point of view.

\section{References}

1. Ando, K. et al. (1995) Matabbors and village development : An account of action research in Dakshin Chamuria village, Bangladesh. Tonan Ajia Kenkyu (J.CSEAS), 33, 39-65 [In Japanese].
2. Ando, K. et al. (1995) Village report of Dakshin Chamuria - The use of locally existing knowledge and thought. In Final review of Joint Study on Rural Development Experiment project, ed. Islam, Md. M., Dhaka JICA \& BARD, Dhaka, 39-80.

3. Ando, K. (1998) Local leadership in rural development and infrastructure building in Bangladesh. In Development AIDs and Bangladesh, ed. Sato, H., Economic Cooperation Ser. 183, Ajiakeizai-kenkyusho, Tokyo, 203-257 [In Japanese].

4. Ando, K. \& Uchida, H. (2003) Matabbors and village development: An account of action research in Dakshin Chamuria village, Bangladesh. In Action research in Bangladesh rural development. ed. Kaida, Y., Commons, Tokyo, 80-113 [In Japanese].

5. JSARD Project Team (1990) Key questions and issues from village-based studies 1986-1989. JSARD Publication No.20, JICA Bangladesh, 65.

6. Planning Commission et al. (1994) Memorandum for the Bangladesh AID group 1994-95. Ministry of Planning, Government of Bangladesh, 23-28. 